\title{
Performance of field-selected clones of Pera sweet orange in Northern São Paulo state, Brazil
}

\author{
Eduardo Sanches Stuchi ${ }^{1,2}$, Eduardo Augusto Girardi ${ }^{1}$, Simone Rodrigues Silva ${ }^{3}$, \\ Luiz Gustavo Parolin², Gerd Walter Müller ${ }^{4} \&$ Luiz Carlos Donadio ${ }^{5}$
}

\section{SUMMARY}

Brazil is the world's largest sweet orange producer, with Pera sweet orange [Citrus sinensis (L.) Osbeck] as the main cultivar and Pera IAC as the most planted clone, due to its good overall horticultural performance and because the plants are preimmunized with the attenuated and protective PIAC isolate of the citrus tristeza virus (CTV). Field-selected elite Pera sweet orange trees selected in Bebedouro, on Northern São Paulo state, were previously submitted to shoot tip grafting and preimmunized against CTV. Thirteen of these clones were evaluated in the present study comparatively with the Pera IAC and the Pera Olímpia clones in a trial set up in 1998 under rain-fed conditions in Bebedouro. All the scions were grafted onto Rangpur lime (C. limonia Osbeck) rootstock. The experiment was conducted following a completely randomized design, with 15 treatments (clones), six replications and one plant in the plot. Stem pitting severity, plant growth, fruit yield and quality were evaluated. As Pera IAC and Pera Olímpia, the thirteen pre-immunized clones did not develop stem pitting symptoms characteristics of Pera reaction to CTV. The Pera clones Milton Teixeira, Fazenda União-35 Anos and Alexandre Maróstica-1949 had similar fruit yield, production efficiency and total soluble solids content in the juice than the Pera IAC standard variety, yet they showed remarkably later fruit maturation.

Index terms: Citrus sinensis, fruit yield and quality, CTV, cross protection.

\section{Desempenho de clones selecionados em campo de laranja Pera no norte do Estado São Paulo, Brasil}

\section{RESUMO}

O Brasil é o principal produtor de laranjas do mundo. A laranja Pera [Citrus sinensis (L.) Osbeck] é a principal variedade de laranja cultivada no Brasil, sendo o clone IAC o mais importante, por ser pré-imunizado com a estirpe fraca e protetiva PIAC do vírus da tristeza dos citros, entre outras boas características. Plantas elite de laranja Pera selecionadas em campo na região de

\footnotetext{
${ }^{1}$ Embrapa Mandioca e Fruticultura, Cruz das Almas, BA, Brasil

${ }^{2}$ Estação Experimental do Agronegócio de Bebedouro, Bebedouro, SP, Brasil

${ }^{3}$ Universidade de São Paulo - USP, Campus de Piracicaba, Piracicaba, SP, Brasil

${ }^{4}$ Instituto Agronômico, Campinas, São Paulo, Brasil, Brasil

${ }^{5}$ Universidade Estadual Paulista - UNESP, Campus de Jaboticabal, Jaboticabal, SP, Brasil

Autor correspondente: Eduardo Sanches Stuchi, Estação Experimental do Agronegócio de Bebedouro, Rodovia Faria Lima, Km 384, CEP 14713-000, Bebedouro, SP, Brasil. E-mail: eduardo.stuchi@embrapa.br
} 
Bebedouro foram previamente microenxertadas e pré-imunizadas, sendo 13 deles comparados neste estudo com os clones padrões Pera IAC e Pera Olímpia em um experimento instalado no município de Bebedouro, no Estado de São Paulo, Brasil, em 1998, em regime de sequeiro. O porta-enxerto foi o limão Cravo (C. limonia Osbeck). O delineamento experimental foi inteiramente casualizado com 15 tratamentos (clones), seis repetições e uma planta por parcela. Avaliaram-se a severidade de caneluras nos ramos, o desenvolvimento vegetativo e a produção e qualidade dos frutos. Não foram observados sintomas de caneluras nos ramos, característicos da reação da laranja Pera ao CTV de média e forte intensidade, para nenhum dos clones avaliados. Os clones Milton Teixeira, Fazenda União-35 Anos e Alexandre Maróstica-1949 apresentaram produção de frutos, eficiência produtiva e teor de sólidos solúveis totais similares às da Pera IAC, porém com maturação de frutos notadamente mais tardia.

Termos de indexação: Citrus sinensis, produção e qualidade de fruto, CTV, proteção cruzada.

\section{INTRODUCTION}

Brazil is the largest sweet orange producer in the world and supplied $23.6 \%$ of global fruit production and $50 \%$ of all the processed orange juice volume in 2016 (FAOSTAT, 2018). Pera is the main sweet orange cultivar grown in Brazil with around 67 million trees that represent 34\% of all area planted with sweet oranges planted in São Paulo and Minas Gerais states (FUNDECITRUS, 2020).

Pera sweet orange has typically small-medium fruits (145 g) with orange-colored pulp, oval shape, smooth skin with protruding oil glands, high juice content (45-61\%), and 3 to 4 seeds per fruit. Pera is a highly productive cultivar, with medium-sized trees with roughly upright branches able to hold ripe fruit on the tree for a several months. Its acuminate leaves have a very distinctive long winged stalk that distinguishes from other sweet orange cultivars. Fruits have mid-season maturation (Pio et al., 2005; Donadio, 1999). Nonetheless, this is the most susceptible commercial sweet orange cultivar to the Citrus tristeza virus (CTV), which stem pitting symptoms was detected for the first time in trees of this cultivar independently of the rootstock (Moreira, 1959).

In Brazil, Costa et al. (1954) first reported the use of cross protection against CTV in citrus and, later on, Folimonova (2013) extensively revised this technique. In 1961, the pre-immunization program was created with the aim of infecting healthy Pera clones with attenuated and protective CTV isolates to promote cross protection against stronger virus strains. In 1968, the Pera Préimunizada clone was obtained, which proved to be a highly productive scion and an alternative against CTV. In the late 1980s, this scion still performed well and was henceforth called as Pera IAC, and became the main Pera sweet orange clone that is cultivated in São Paulo State (Müller et al., 1999). After 40 years of continuous use, its mild CTV protective isolate PIAC conferring cross protection remains stable, and the Pera IAC plants have no or few stem pitting symptoms and produce fruits with standard size and quality. It was one of the most productive scions in trials comparing different Pera clones in the Paraná state (Müller et al., 1999; Leonel et al., 2015; Baba et al., 2014).

Pera is considered a Brazilian cultivar, although its origin is not completely known and it has been associated with other pear-shaped sweet oranges cultivars from the United States, Spain, Portugal and Italy, such as Lamb Summer, Berna Peret, Verna Peret, Alberola, Peret, Pera de Vidigueira, Brasileira, Ovale and Calabrese (Donadio, 1999; Hodgson, 1967). In most of the countries, these pear-shaped varieties arose around the same time, i.e., by the end of the $19^{\text {th }}$ century, except Lamb Summer, with undefined date of origin. All those varieties show off-season flowering (Donadio et al., 1999).

In Brazil, a large number of Pera-type clones has been described since 1933 (Donadio et al., 1999; Salibe et al., 2002). Considerable differences have been observed between the clones regarding several characteristics, with Pera Olímpia and Pera D6 selected as important regional clones too (Teófilo Sobrinho et al., 1990; Domingues et al., 1997; Domingues et al., 2004; Carvalho et al., 2015; Passos et al., 2009; Baba et al., 2014; Giampani et al., 2016). This large variability may be attributed to the occurrence of spontaneous mutations (Donadio et al., 1999), even though several clones that were naturally infected with attenuated CTV strains were also selected and planted in commercial orchards (Salibe et al., 2002).

Through a collaborative project of Bebedouro Experimental Citrus Station (EECB) with Coopercitrus and the former Virology Section of the IAC, started in 1989, elite trees of Pera sweet orange old clones originated in the Bebedouro region were selected in the field. These plants were very productive, did not show pronounced stem pitting and had no blight or tristeza symptoms. 
Those selected elite plants were biologically indexed and submitted to in vitro shoot apex micro-grafting technique and, subsequently, preimmunized with the mild CTV protective isolate of PIAC. The resulting plants had no variations of type and showed no juvenile characteristics, and those micro-grafted and PIAC preimmunized clones were evaluated in several field trials (Donadio et al., 1999; Müller et al., 2002).

In this work, the long-term performance of 13 of those Donadio et al. (1999) and Müller et al. (2002) field-selected and preimmunized clones of Pera sweet orange was evaluated and compared to the commercial standards Pera IAC and Pera Olímpia.

\section{MATERIAL AND METHODS}

Thirteen clones propagated from elite Pera sweet orange trees [Citrus sinensis (L.) Osbeck] selected in the field in the Bebedouro region, previously micro-grafted and preimmunized with the PIAC CTV isolate at the former Phytopathological Virology Section at the Instituto Agronômico (IAC), in Campinas-SP (Müller et al., 2002), were compared with the Pera IAC and Pera Olímpia standards, all of them grafted on Rangpur lime (C. limonia Osbeck). The experiment was conducted following a completely randomized design, with 15 treatments, six replications and one tree in the plot. The clones are described in Table 1.

The trial was installed in Bebedouro, on the Northern region of São Paulo state $\left(20^{\circ} 53^{\prime} 16^{\prime \prime} \mathrm{S}, 48^{\circ} 28^{\prime} 11\right.$ 'W, $601 \mathrm{~m}$. a. s. 1.). The prevailing climate in the region is Aw (Köppen), with mild and dry winter and hot and rainy summer, annual mean rainfall of 1,420 mm and mean air temperature of $24^{\circ} \mathrm{C}$ in the $1998-2008$ evaluation period. The trial was planted in October 1998 at $7 \mathrm{~m} \times 4 \mathrm{~m}$ spacing (357 plants ha ${ }^{-1}$ ) with no supplemental irrigation.

The soil was a typical dystrophic red latosol, endoallic, acid soil, with a moderate $\mathrm{A}$-horizon and medium texture ( $38 \%$ clay content; $\mathrm{pH} \mathrm{CaCl}_{2}=5.6$ and $\mathrm{CEC}=51 \mathrm{mmol}_{\mathrm{c}}$ $\mathrm{dm}^{-3}$ at $0-20 \mathrm{~cm}$ soil depth). Standard cultural practices for sweet orange cultivation in São Paulo state were adopted and the trees were not pruned. Mean annual nutrients amounts applied per plant were $242 \mathrm{~g} \mathrm{~N}, 85 \mathrm{~g}$ $\mathrm{P}_{2} \mathrm{O}_{5}$ and $158 \mathrm{~g} \mathrm{~K}_{2} \mathrm{O}$. The experimental plot was eradicated in 2008 after scouting some plants with huanglongbing (HLB) symptoms, in an attempt to keep the area free from HLB at that time.

The occurrence of CTV symptoms was performed for all the trees in the experiment. Four $20 \mathrm{~cm}$ length branches segments per tree had the bark removed and were evaluated by visual assessment of stem pitting symptoms using a five-score rating scale (scores 1-5 for

Table 1. Experimental designation, origin and age of the 13 micro-grafted and preimmunized clones of Pera evaluated in comparison to two commercial ones in the field in the region of Bebedouro, São Paulo, Brazil

\begin{tabular}{|c|c|c|c|c|}
\hline \multirow{2}{*}{$\begin{array}{c}\text { Clone experimental } \\
\text { designation }\end{array}$} & \multicolumn{3}{|c|}{ Origin of the clone } & Age* \\
\hline & Farm & Grower & Municipality & (years) \\
\hline IAC & CCSM & Instituto Agronômico & Cordeirópolis & - \\
\hline Olímpia & CCSM & Instituto Agronômico & Cordeirópolis & - \\
\hline Fazenda União - 35 Anos & União & Família Medeiros & Bebedouro & 35 \\
\hline Sérgio Pimenta - 1946 & São José & Sérgio Pimenta & Olímpia & 42 \\
\hline Pera 2 & Santa Irene & Aracy Marques Caldeira & Bebedouro & n. a. \\
\hline Pera 3 & Santa Irene & Aracy Marques Caldeira & Bebedouro & n. a. \\
\hline Pera 4 & Santa Irene & Aracy Marques Caldeira & Bebedouro & n. a. \\
\hline Fazenda Vila São João 1948 & São João & Otto Mahle & Bebedouro & 40 \\
\hline Milton Teixeira & Santa Terezinha & Milton Teixeira & Bebedouro & n. a. \\
\hline Gibran - 1959 & São Paulo & José Salomão Gibran & Viradouro & 29 \\
\hline Gibran - 1958 & São Paulo & José Salomão Gibran & Viradouro & 30 \\
\hline Alexandre Maróstica - 1949 & Santa Inês & Alexandre Maróstica & Terra Roxa & 39 \\
\hline Ivan Aidar - 1962 & Nata & Ivan Aidar & Severínia & 27 \\
\hline Felício Sasso - 1959 & Nova Aliança & Felício Sasso & Monte Azul Paulista & 29 \\
\hline Nair Hernandes - 1954 & Palmeiras & Nair T. Hernandes & Bebedouro & 34 \\
\hline
\end{tabular}

*Age of the tree in the field at initial budwood collection. CCSM = Sylvio Moreira Citrus Center. (-) not applicable. (n. a.) $=$ not available 
no and very strong symptom intensity, respectively) according Donadio et al. (1974).

From 2004 to 2008, measurements of tree height (H) and mean tree width were performed with a ruler, and the tree volume $(\mathrm{V})$ was calculated by using the formula: $\mathrm{V}=(2 / 3) \pi r^{2} h$, where $\mathrm{r}$ is the tree mean radius and $\mathrm{h}$ is the tree height. Only data from 2008 is presented, and the mean V variation for the 2004-2008 period was calculated as the plant growth rate.

In the 2001-2008 periods, fruit yield was annually computed by weighing the fruits on a digital balance, and the mean results were expressed in $\mathrm{kg} \mathrm{tree}^{-1}$. Mean production efficiency was calculated from the ratio between fruit yield and tree volume in 2004-2008, and expressed in $\mathrm{kg} \mathrm{m}^{-3}$. The alternate bearing index (ABI) was calculated from 2001 to 2008 , as ABI $=1 /(n-1) \times\left\{\left|a_{2}-a_{1}\right|\right.$ $\left.\left(a_{2}+a_{1}\right)+\left|a_{3}-a_{2}\right| /\left(a_{3}+a_{2}\right)+\ldots+\left|a_{n}-a_{n-1}\right| /\left(a_{n}+a_{n-1}\right)\right\}$, where $\mathrm{n}=$ number of years and $\mathrm{a}_{1}, \mathrm{a}_{2}, \mathrm{a}_{\mathrm{n}} \ldots \mathrm{a}_{\mathrm{n}-1}=$ yield of the corresponding years (Pearce \& Dobersek-Urbanc, 1967). Early bearing of the clones was calculated by the relation between the cumulative yield in the first four commercial harvests (2001-2004) and cumulative fruit yield in the whole evaluated period (2001-2008).

Fruit quality was assessed from 2001 to 2008, except by 2007, on samples of ten fruits collected from each plot, always in August after maturation was visually assessed. For the purpose of comparing the maturation period between the different clones, samples were also collected for fruit quality analysis between August and October in 2004 with an interval of 20 days. The following variables were measured, with the means calculated for the period: (i) fruit weight, length and diameter; (ii) total soluble solids content (TSS), by direct reading in a digital refractometer (Palette PR-101, ATAGO, Tokyo, Japan) and expressed in Brix; (iii) titratable acidity (TA), by juice titration with $0.3125 \mathrm{~N} \mathrm{NaOH}$ and expressed as percentage of citric acid per $100 \mathrm{~mL}$ of juice; (iv) maturation index, calculated by the ratio of TSS:TA; (v) juice content (JC, \%), from the relationship between the weight of the extracted juice (Otto 1800 juice extractor, OIC, Limeira, São Paulo, Brazil) and the fruit sample weight; and (vi) the technological index (TI), expressed as ( $\left.\mathrm{kg} \mathrm{TSS} \mathrm{box}{ }^{-1}\right)$ and calculated by $\mathrm{TI}=[\mathrm{JC} \times \mathrm{TSS} \times 40.8] \times 10,000^{-1}$ where $40.8 \mathrm{~kg}$ is the weight of a standard orange fruit box.

Data analysis was performed by using the SISVAR 5.3 statistical software. Data were submitted to the analysis of variance and the means were grouped by the ScottKnott's test $(\mathrm{P}<0.05)$ under the statistical assumptions of normal error distribution and homoscedasticity of variance. The fruit weight and diameter were transformed by $\sqrt{ }(x+1.0)$. The 'Felício Sasso-1959' clone was not analyzed for the variables ABI and early bearing because of tree losses in the initial years.

\section{RESULTS AND DISCUSSION}

None of the studied clones developed stem pitting symptoms nor stunted or chlorotic trees associated with the Tristeza disease (data not shown). In 2008, after 10 years from planting in the field, no differences in tree width, height and volume were evident among all clones. Moreover, no significant differences in the mean tree growth rate in the 2001-2008 periods were found between the 15 clones (Table 2).

In the 2001-2008 periods, the 15 clones produced similar mean fruit yield, and the mean early bearing percentage in the first four commercial harvests was 33\%. In addition, no differences occurred among all the clones for the alternate bearing index (Table 3).

The Felício Sasso-1959, Fazenda Vila São João-1948 and Sérgio Pimenta-1946 clones had lower yield efficiency (3.6 $\mathrm{kg} \mathrm{m}^{-3}$ mean value), followed by the group including Pera IAC, Ivan Aidar-1962 and Pera $2\left(4.40 \mathrm{~kg} \mathrm{~m}^{-3}\right.$ mean value). In the 2006-2008 period, highest yield efficiencies, varying from 4.59 to $5.54 \mathrm{~kg} \mathrm{~m}^{-3}$, were recorded among the clones Pera Olímpia, Pera 3, Pera 4, Milton Teixeira, Gibran-1959, Gibran-1958, Alexandre Maróstica-1949, Nair Hernandes-1954 and Fazenda União-35 Anos (Table 3).

Felício Sasso-1959 clone had the largest fruit weight among the clones, $207 \mathrm{~g}$. The other clones were divided into two groups regarding fruit size: one group of clones, including Pera IAC, Fazenda Vila São João-1948, Gibran1959, Alexandre Marostica-1949 and Pera 2, with mean fruit weight between 180 to $185 \mathrm{~g}$; and a second group formed by Pera Olímpia, Fazenda União-35 Anos, Sérgio Pimenta-1946, Pera 3, Pera 4, Ivan Aidar-1962 and Nair Hernandes-1954, Milton Teixeira and Gibran-1958 with mean fruit weight between 160 to $175 \mathrm{~g}$ (Table 4).

The Felício Sasso-1959 clone also showed larger fruit diameter $(7.14 \mathrm{~cm})$, followed by the Alexandre Maróstica-1949 clone $(6.90 \mathrm{~cm})$. All other clones produced fruits with smaller diameter, averaging $6.70 \mathrm{~cm}$. Two groups of clones with different mean fruit height were identified: a group including the Fazenda Vila São João-1948, Milton Teixeira, Gibran-1959, Felício Sasso-1959 and Pera 2 clones, with fruit height $>7.34 \mathrm{~cm}$, and a second group formed 
Table 2. Plant size of 13 micro-grafted and preimmunized clones and two commercial standards of Pera sweet orange grafted onto Rangpur lime in 2008 (after 10 years from planting) and mean tree volume growth rate in the 2004-2008 period. Bebedouro, São Paulo, Brazil

\begin{tabular}{|c|c|c|c|c|c|c|c|c|}
\hline \multirow{2}{*}{ Clone } & & & & & \multirow{2}{*}{$\frac{\text { Volume }}{\left(\mathrm{m}^{3}\right)}$} & \multicolumn{3}{|c|}{ Growth rate } \\
\hline & \multicolumn{4}{|c|}{$\ldots-\ldots(m)-\ldots$} & & \multicolumn{3}{|c|}{$\left(m^{3}\right.$ year $\left.^{1}\right)$} \\
\hline Pera IAC & 3.27 & $\mathrm{a}$ & 2.76 & $\mathrm{a}$ & 16.22 & $\mathrm{a}$ & 1.77 & $\mathrm{a}$ \\
\hline Pera Olímpia & 2.96 & a & 2.52 & a & 11.80 & a & 1.07 & a \\
\hline Fazenda União-35 Anos & 2.64 & a & 2.14 & $\mathrm{a}$ & 11.77 & $\mathrm{a}$ & 1.91 & $\mathrm{a}$ \\
\hline Sérgio Pimenta-1946 & 3.23 & $\mathrm{a}$ & 2.69 & $\mathrm{a}$ & 14.81 & $\mathrm{a}$ & 1.71 & a \\
\hline Pera 2 & 3.36 & $\mathrm{a}$ & 2.81 & a & 16.99 & $\mathrm{a}$ & 1.93 & a \\
\hline Pera 3 & 3.21 & a & 2.57 & a & 14.17 & a & 1.62 & a \\
\hline Pera 4 & 3.14 & a & 2.53 & $\mathrm{a}$ & 13.13 & $\mathrm{a}$ & 1.49 & $\mathrm{a}$ \\
\hline Fazenda Vila São João-1948 & 2.77 & a & 2.39 & a & 14.07 & a & 1.87 & a \\
\hline Milton Teixeira & 3.28 & a & 2.88 & a & 16.67 & $\mathrm{a}$ & 1.45 & $\mathrm{a}$ \\
\hline Gibran-1959 & 3.22 & $\mathrm{a}$ & 2.50 & $\mathrm{a}$ & 13.65 & $\mathrm{a}$ & 1.62 & a \\
\hline Gibran-1958 & 3.08 & $\mathrm{a}$ & 2.18 & $\mathrm{a}$ & 11.20 & $\mathrm{a}$ & 1.26 & a \\
\hline Alexandre Maróstica-1949 & 3.34 & $\mathrm{a}$ & 2.73 & $\mathrm{a}$ & 16.36 & $\mathrm{a}$ & 2.05 & $\mathrm{a}$ \\
\hline Ivan Aidar-1962 & 2.44 & $\mathrm{a}$ & 1.93 & $\mathrm{a}$ & 9.04 & $\mathrm{a}$ & 1.18 & $\mathrm{a}$ \\
\hline Felício Sasso-1959 & 2.11 & $\mathrm{a}$ & 1.75 & a & 9.42 & a & 1.98 & a \\
\hline Nair Hernandes-1954 & 3.13 & $\mathrm{a}$ & 2.31 & $\mathrm{a}$ & 11.98 & a & 1.23 & a \\
\hline Coefficient of variation (\%) & 26.84 & & 26.27 & & 39.46 & & 47.17 & \\
\hline
\end{tabular}

Means followed by the same letter in columns belong to the same group by the Scott-Knott's test $(\mathrm{P}<0.05)$.

Table 3. Mean fruit yield, alternate bearing index (ABI), early bearing percentage (EB) and yield efficiency (YE) in 13 micro-grafted and preimmunized and two commercial clones of Pera sweet orange grafted onto Rangpur lime in the 2001-2008 period (first to eighth harvest seasons). Bebedouro, São Paulo, Brazil.

\begin{tabular}{|c|c|c|c|c|c|c|c|c|}
\hline Clone & \multicolumn{2}{|c|}{$\begin{array}{l}\text { Yield } \\
\quad\left(\mathrm{kg} \text { tree }^{-1}\right)\end{array}$} & \multicolumn{2}{|l|}{$\mathrm{ABI}$} & \multicolumn{2}{|l|}{$\frac{E B *}{(\%)}$} & \multicolumn{2}{|c|}{$\begin{array}{l}\mathrm{YE}^{* *} \\
\quad\left(\mathrm{~kg} \mathrm{~m}^{-3}\right)\end{array}$} \\
\hline Pera IAC & 37.3 & a & 0.38 & $\mathrm{a}$ & 37.4 & $\mathrm{a}$ & 4.15 & $\mathrm{~b}$ \\
\hline Pera Olímpia & 35.3 & $\mathrm{a}$ & 0.24 & $\mathrm{a}$ & 40.5 & $\mathrm{a}$ & 4.59 & $\mathrm{a}$ \\
\hline Fazenda União-35 Anos & 43.5 & $\mathrm{a}$ & 0.35 & $\mathrm{a}$ & 30.3 & $\mathrm{a}$ & 5.54 & $\mathrm{a}$ \\
\hline Sérgio Pimenta-1946 & 30.1 & $\mathrm{a}$ & 0.25 & $\mathrm{a}$ & 32.6 & a & 3.32 & $\mathrm{c}$ \\
\hline Pera 2 & 39.4 & $\mathrm{a}$ & 0.21 & $\mathrm{a}$ & 35.7 & $\mathrm{a}$ & 4.75 & $\mathrm{~b}$ \\
\hline Pera 3 & 39.9 & $\mathrm{a}$ & 0.22 & $\mathrm{a}$ & 31.7 & $\mathrm{a}$ & 4.84 & $\mathrm{a}$ \\
\hline Pera 4 & 42.4 & $\mathrm{a}$ & 0.21 & $\mathrm{a}$ & 38.3 & a & 5.06 & $\mathrm{a}$ \\
\hline Fazenda Vila São João-1948 & 31,1 & $\mathrm{a}$ & 0.28 & a & 31.5 & $\mathrm{a}$ & 3.94 & $\mathrm{c}$ \\
\hline Milton Teixeira & 53.6 & $\mathrm{a}$ & 0.27 & $\mathrm{a}$ & 37.7 & $\mathrm{a}$ & 4.81 & $\mathrm{a}$ \\
\hline Gibran-1959 & 38.9 & a & 0.28 & a & 39.3 & a & 4.90 & a \\
\hline Gibran-1958 & 38.7 & $\mathrm{a}$ & 0.17 & $\mathrm{a}$ & 32.8 & $\mathrm{a}$ & 5.49 & $\mathrm{a}$ \\
\hline Alexandre Maróstica-1949 & 51.2 & $\mathrm{a}$ & 0.23 & $\mathrm{a}$ & 24.1 & $\mathrm{a}$ & 5.18 & $\mathrm{a}$ \\
\hline Ivan Aidar-1962 & 29.4 & a & 0.14 & a & 21.4 & $\mathrm{a}$ & 4.30 & $\mathrm{~b}$ \\
\hline Felício Sasso-1959 & 33.6 & $\mathrm{a}$ & - & & - & & 3.50 & $\mathrm{c}$ \\
\hline Nair Hernandes-1954 & 37.1 & $\mathrm{a}$ & 0.24 & $\mathrm{a}$ & 34.0 & $\mathrm{a}$ & 4.81 & $\mathrm{a}$ \\
\hline Coefficient of variation $(\%)$ & 37.82 & & 51.38 & & 47.41 & & 12.44 & \\
\hline
\end{tabular}

Means followed by the same letter in columns belong to the same group by the Scott-Knott's method $(\mathrm{P}<0.05)$. (-) not evaluated. * Percentage of total yield in the first four commercial harvests in relation to total accumulated yield in the evaluation period.

**Mean in the 2004-2008 period 


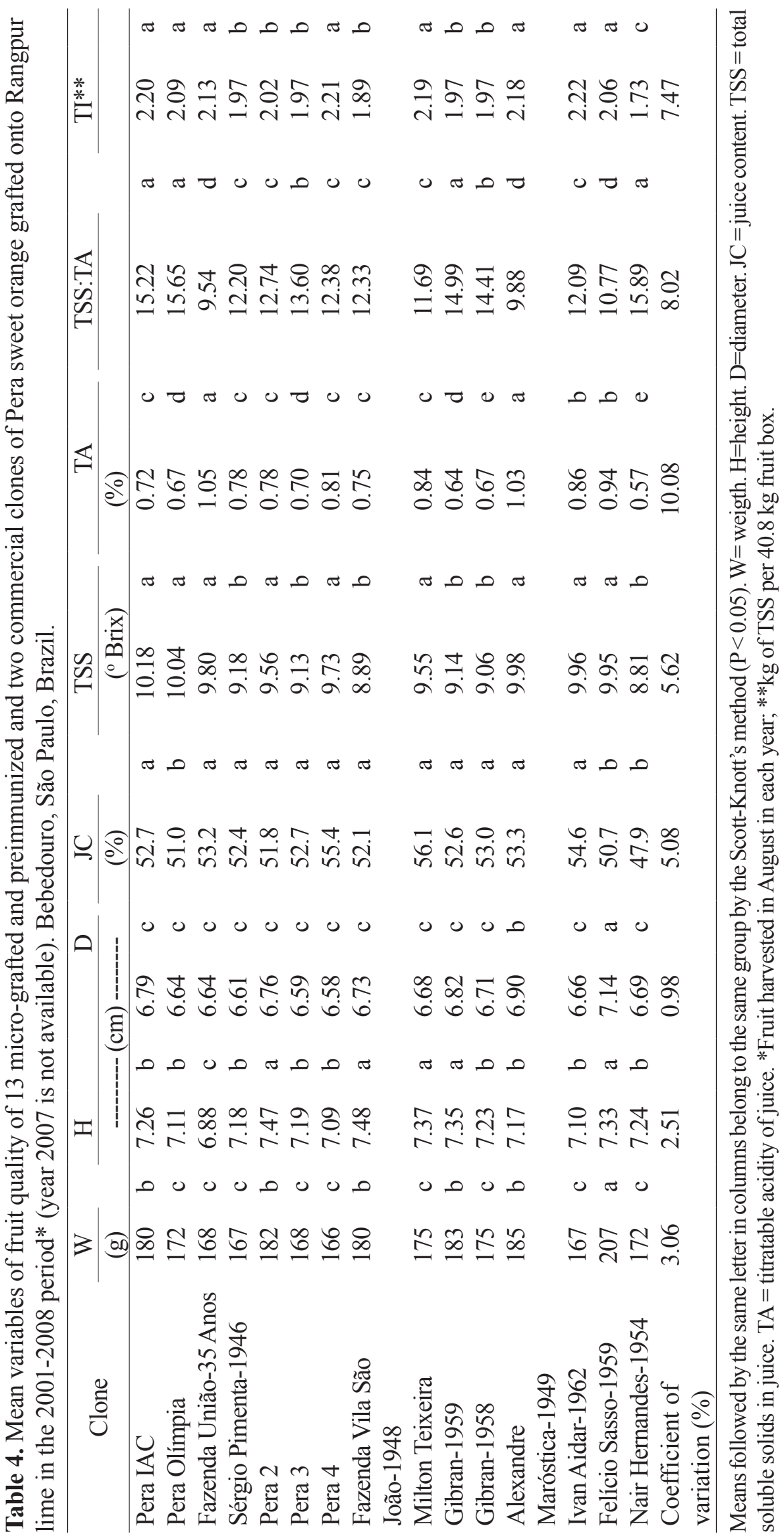


by Pera IAC, Pera Olímpia, Sérgio Pimenta-1946, Pera 3, Pera 4, Gibran-1958, Nair Hernandes-1954, Alexandre Maróstica-1949 and Ivan Aidar-1962 clones, with mean fruit height varying from 7.09 to $7.25 \mathrm{~cm}$. The Fazenda União-35 Anos clone had the smallest fruit height, with only $6.89 \mathrm{~cm}$. Spheroidal fruit shape was observed in the Alexandre Maróstica-1949, Fazenda União-35 Anos and Felício Sasso-1959 clones, while in all the other clones the fruits were typically pear-shaped (Table 4).

The clones were divided into two different groups regarding the TSS content. A group formed by the Pera 3, Sérgio Pimenta-1946, Fazenda Vila São João-1948, Gibran1958, Gibran-1959 and Nair Hernandes-1954 clones had TSS between 8.8 to $9.2^{\circ}$ Brix, while the other clones had larger TSS contents, varying between 9.5 to $10.2{ }^{\circ}$ Brix. The Pera Olímpia, Felício Sasso and Nair Hernandes yielded lower juice contents, between 47.9 and 51\%. The others clones were similar in a range from 51.8 to $56.1 \%$ of juice content (Table 4 ).

In the analysis of the TA and TSS: TA ratio mean values, several groups of clones were identified, which corroborates the large variation in the maturation season among the studied clones. Fruits of the Fazenda União-35 Anos and Alexandre Marostica-1949 clones were more acidic (Table 4). According to the Figure 1, that illustrates the soluble solids: acidity ratio evolution from August to October 2004, those clones presented later maturation season, contrasting with the Pera IAC and Pera Olímpia standard clones that presented lower acid levels in August, when the fruits were analyzed in the other years, and reached the minimum index 12 yet in the first of the four ratio evaluations. Ramos (2015) reported that Pera IAC accumulated $3375{ }^{\circ} \mathrm{C}$ day to reach the maturation point (ratio=12) contrarily to Milton Teixeira that needed $4068^{\circ} \mathrm{C}$ day, and Alexandre Maróstica with the highest $\Sigma \mathrm{DD}\left(4553{ }^{\circ} \mathrm{C}\right.$ day) to reach the harvest point, indicating that those material might reach ratio 12 in November and December, respectively, in Iaras, São Paulo state, conditions.

The Pera IAC, Pera Olímpia, Fazenda União-35 Anos, Pera 4, Milton Teixeira, Alexandre Maróstica-1949, Ivan Aidar-1962 and Felício Sasso-1959 clones had higher TI values, between 2.06 to $2.22 \mathrm{~kg} \mathrm{TSS} \mathrm{box}^{-1}$. The other clones had TI values varying from 1.97 to 2.02 , except on the Nair Hernandes-1954 clone, with only $1.73 \mathrm{~kg}$ TSS box ${ }^{-1}$ (Table 4).

Currently, the Pera IAC is the most cultivated sweet orange clone in commercial orchards in Brazil, with some use of Pera Olímpia as well. Both of these standard clones produced high fruit yields and none of the fieldselected clones outperformed them in production in the Bebedouro region. Nonetheless, some of the regional
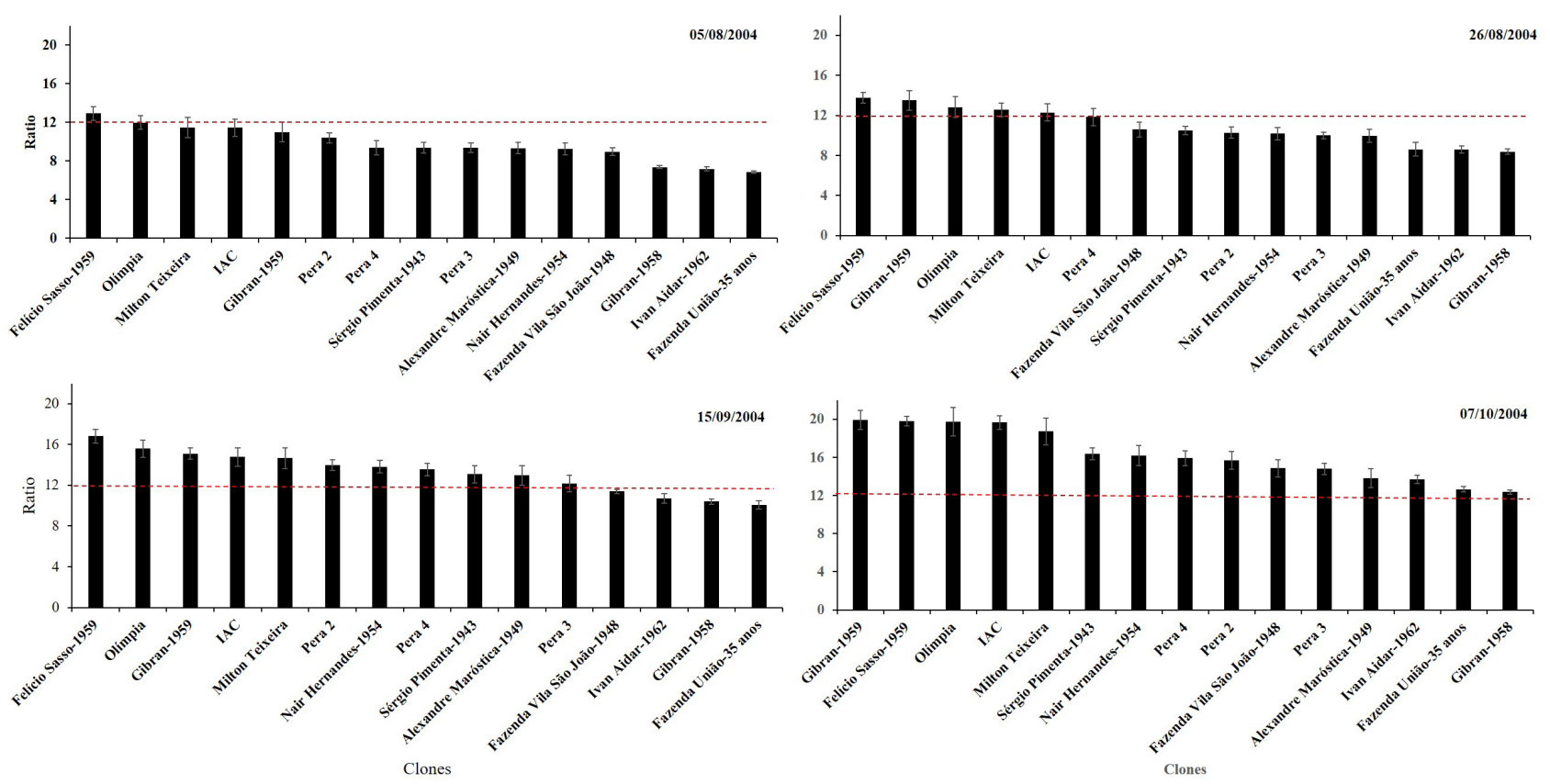

Figure 1. Fruit maturity index (ratio) evolution from August to October 2004 of 15 Pera sweet orange clones grafted onto Rangpur lime in Bebedouro, São Paulo, Brazil. 
clones produced similar yields, but had later maturation season. This characteristic may be important for orchard planning and extending the harvest season and may increase grower's profit.

In a previous study, some of the regional clones were rated with mean stem pitting scores varying from 0.25 to 2.25, in a 0-4 rating scale (Donadio et al., 1974), except on the Pera 2, Pera 3, Pera 4, Pera IAC and Pera Olímpia clones that were not evaluated. However, in this study, no stem pitting symptoms were observed in any of the clones, which suggests the effectiveness of their pre-immunization against CTV. Nonetheless, the region where the trial was conducted has no historical incidence of the more severe Capão Bonito CTV-strain (Müller et al., 1968), and has higher mean air temperatures than the milder south and southeastern regions of São Paulo state as observed by Carvalho et al. (2015). Therefore, in order to verify the tolerance to more severe CTV strains causing stem pitting, it is suggested to evaluate the selected 'Pera' sweet orange clones in colder regions, because high temperatures reduce the severity of tristeza symptoms and do not allow identifying differences on the clone's reaction to the virus (Roistacher et al., 1974).

Higher cumulative yield was recorded in plants of the Milton Teixeira clone, but it did not significantly differ from the Pera IAC and Pera Olímpia clones. Small differences among Pera clones were also reported in a study conducted in Cambé, in the Paraná state; contrarily, in another trial carried out in Londrina, Paraná state, three Pera selections had outstanding performance (Giampani et al., 2016), which emphasizes the influence of local conditions on the clone performance.

The Pera IAC clone had lower yield efficiency $\left(4.15 \mathrm{~kg} \mathrm{~m}^{-3}\right)$ as compared to the Pera Olímpia clone $\left(4.59 \mathrm{~kg} \mathrm{~m}^{-3}\right)$ and to the Pera 3, Pera 4, Milton Teixeira, Gibran-1959, Gibran-1958, Alexandre Maróstica-1949, Nair Hernandes-1954 and Fazenda União-35 Anos clones (5.54 $\mathrm{kg} \mathrm{m}^{-3}$, in average). Trees of the D-6 and IPR 159 Pera selections showed similar yield efficiency to the Pera IAC and Pera Olímpia clones. All the clones included in the present study showed lower yield efficiency than the Pera Prée-imunizada in the Paraná state (Baba et al., 2014; Giampani et al., 2016). Yield efficiency appears to be dependent from others factors as rootstock cultivar, climate, soil properties, and cultural practices than genetic characteristic of the selection.

Excepting by Felício Sasso-1959, all the evaluated Pera sweet orange clones yielded $33 \%$ of the total production in the first four commercial harvests, in average, which confirms that micro-grafting and cross protection usually cause no rejuvenation as reported by other authors (Navarro \& Juárez, 2007).

All the clones evaluated in this study had larger fruit weight than that reported by Figueiredo (1991) and Nonino (1995) for Pera sweet orange in São Paulo state, of approximately $145 \mathrm{~g}$. Otherwise, the clones herein evaluates had similar fruit weight to the mean value of $200 \mathrm{~g}$ for Pera sweet orange as reported by Donadio et al. (1999) and Passos et al. (2009). All the evaluated clones had also juice contents $<57 \%$, lower than the average JC values of 56.7 to $60.6 \%$ reported for Pera sweet oranges (Nonino, 1995; Donadio, 1999). In addition, all the TSS contents observed in this study were lower than the average values of 11.1 to $12.1^{\circ}$ Brix defined for the Pera cultivar (Figueiredo 1991; Nonino, 1995; Donadio, 1999). For all the clones, small variations of TSS contents were observed among years, without extreme values.

According to Figueiredo (1991) the Pera IAC sweet orange cultivar has a mean TA of $0.95 \%$, but in this study it showed $0.75 \%$, which is still within the interval of 0.58 to $0.86 \%$ reported by Nonino (1995) for this cultivar. The Fazenda União-35 Anos, Alexandre Maróstica-1949, Felício Sasso-1959 and Ivan Aidar-1962 clones produced fruit with higher TA values than Pera IAC, even higher than the maximum value reported by Nonino (1995).

The average JC, TSS and TA values observed in this study were lower than those reported in Florida for seven Pera clones grafted on Swingle citrumelo, including the Pera Pre-imunizada (= Pera IAC) and Pera Vacinada ones, where graft incompatibility occurred for all the clones, except Perão and Acidless. In that trial, all the evaluated clones showed different maturation times (Castle \& Baldwin, 2011), similarly to the results observed in the present study.

The observed differences in the TSS:TA ratio among clones indicate the existence of selections with remarkably later maturation than the Pera IAC (15.2), such as the Fazenda União-35 Anos (9.5), Alexandre Maróstica-1949 (9.8) and Felício Sasso-1959 (10.8) clones, and, to a lesser extent, also the Milton Teixeira clone (11.7), which are much lower than the 12.9-minimum value reported for the Pera cultivar (Nonino, 1995). Differences in the maturation season between Pera sweet orange clones have been previously reported (Teófilo Sobrinho et al., 1990; Domingues et al., 1997, 2004), and may be useful for extending the harvest season of this cultivar. Additionally, the selected clones should also have other valuable characteristics, such as fruit yield, yield efficiency and 
TSS content at least similar to those of Pera IAC, such as the Milton Teixeira, the Fazenda União-35 Anos and the Alexandre Maróstica-1949 clones.

\section{CONCLUSIONS}

None of the Pera orange clones evaluated showed symptoms of stem pitting, suggesting that pre-immunization with the PIAC CTV isolate was efficient in protecting the plants under the climate conditions of Bebedouro, SP.

Overall tree performance was very similar among the field-selected, micro-grafted and preimmunized Pera clones, with no substantial genetic gain in relation to the Pera IAC and Pera Olímpia sweet orange commercial varieties.

Due to the later fruit maturation, the Milton Teixeira, Fazenda União-35 Anos and Alexandre Maróstica-1949 clones are potential alternatives for cultivation in the northern region of São Paulo state, allowing the extension of the harvest season of the Pera standard variety.

\section{ACKNOWLEDGEMENTS}

The authors acknowledge Fundação de Amparo à Pesquisa do Estado de São Paulo (FAPESP) for the financial support (Processes 1995/09283-5 and 2004/16077-3), Conselho Nacional de Desenvolvimento Científico e Tecnológico (CNPq) for Research fellowship for the first author, and the Bebedouro Experimental Citrus Station (EECB) for the experimental area, and valuable technical and administrative support.

\section{REFERENCES}

Baba, V. Y., Giampani, J. S., Tazima, Z. H., Yada, I. F. U., Paccola-Meirelles, L. D., \& Leite Júnior, R. P. (2014). Agronomic performance of Pera and related sweet orange accessions naturally infected with Citrus tristeza virus in northern Paraná State, Brazil. Tropical Plant Pathology, 39, 442-448. http://dx.doi.org/10.1590/ S1982-56762014000600004.

Carvalho, S. A., Latado, R. R., Silva, L. F. C., \& Muller, G. W. (2015). Agronomic performance of thirty two clones of 'Pera' sweet orange in São Paulo State, Brazil. Acta
Horticulturae, 1065, 281-291. Retrieved in 2019, October 30, from http://www.actahort.org/books/1065/1065_34.htm Castle, W. S., \& Baldwin, J. C. (2011). Young-tree performance of juvenile sweet orange scions on swingle citrumelo rootstock. HortScience, 46(4), 541-552. http:// dx.doi.org/10.21273/HORTSCI.46.4.541.

Costa, A. S., Grant, T. J., \& Moreira, S. (1954). Behavior of various citrus rootstock-scion combinations following inoculation with mild and severe strains of tristeza vírus. Proceeding of the Florida State Horticultural Society 67: 26-30.

Domingues, E. T., Mattos Jr, D., Teófilo Sobrinho, J., Pompeu Junior, J., Figueiredo, J. O., \& Sugahara, V. Y. (1997). Seleção de clones de laranja Pêra quanto ao período de maturação com o uso da análise de agrupamento. Revista Brasileira de Fruticultura, 19(1), 89-101.

Domingues, E. T., Teófilo Sobrinho, J., Pompeu Junior, J., Figueiredo, J. O., \& Tulmann Neto, A. (2004). Caracterização de onze clones de laranja Pêra e seis variedades assemelhadas. Laranja, 25(1), 111-138.

Donadio, L. C. (1999). Laranja Pêra. Boletim Citrícola, 11, 1-56. Retrieved in 2019, October 30, from http:// www.estacaoexperimental.com.br/documentos/BC_11.pdf

Donadio, L. C., Figueiredo, J. O., Rodriguez, O., \& Teófilo Sobrinho, J. (1974). Behavior of seedling lines of citrus infected naturally with tristeza virus In Proceedings of the 6th International Organization of Citrus Virologists (pp. 89-93). Richmond: University of California.

Donadio, L. C., Stuchi, E. S., Pozzan, M., \& Sempionato, O. C. (1999). Novas variedades e clones de laranja doce para indústria. Boletim Citrícola, 8, 1-42. Retrieved in 2019, October 30, from http://www.estacaoexperimental. com.br/documentos/BC_08.pdf

Figueiredo, J. O. (1991). Variedades copa de valor comercial. In O. Rodriguez, F. Viégas, J. Pompeu Junior, \& A. A. Amaro (Eds.), Citricultura brasileira (2. ed., Vol. 1, pp. 228-264). Campinas: Fundação Campinas.

Figueiredo, J. O. (1991). Variedades copas. In O. Rodriguez, F. Viegas, J. Pompeu Junior \& A. A. Amaro (Eds.), Citricultura brasileira (2. ed.). Campinas: Fundação Cargill.

Folimonova, S. Y. (2013). Developing an understanding of cross-protection by Citrus tristeza virus. Frontiers in Microbiology, 4(76), 1-9. http://dx.doi.org/10.3389/ fmicb.2013.00076.

Food and Agriculture Organization Corporate Statistical Database - FAOSTAT. (2018). Food and agricultural 
commodities production. Retrieved in 2018, October 2, from http://www.fao.org/faostat/en/\#data/QC $</$ eref $>$ from Fundo de Defesa da Citricultura-FUNDECITRUS. (2020). Inventário de árvores e estimativa da safra de laranja 2020/21 do cinturão citrícola de São Paulo e Triângulo/Sudoeste Mineiro (pp. 111). Araraquara: FUNDECITRUS. Retrieved in 2020, September 1, from https://www.fundecitrus.com. br/pdf/pes_relatorios/2020_06_25_Invent\%C3\%A1rio_e_ Estimativa_do_Cinturao_Citricola_2020-20211.pdf

Giampani, J. S., Tazima, Z. H., Baba, V. Y., Yada, I. F. U., \& Leite Júnior, R. P. (2016). Citrus tristeza disease severity and agronomic performance of Pera orange cultivars and selections in the North and Northwest regions of the State of Paraná, Brazil. Revista Brasileira de Fruticultura, 38(3), e-073. http://dx.doi.org/10.1590/0100-29452016073.

Hodgson, R. W. (1967) Horticultural varieties of citrus. In W. Reuther, L. D. Batchelor \& H. J. Webber (Eds.), The citrus industry (pp. 431-591). Riverside: University of California.

Leonel, W. M. S., Corazza, M. J., Zanutto, C. A., Müller, G. W., Carvalho, S. A., \& Nunes, W. M. C. (2015). Stability of citrus tristeza virus protective isolate Pêra IAC according to SSCP analysis of old and new lines of three sweet orange varieties. Summa Phytopathologica, 41(1), 8-12. http://dx.doi.org/10.1590/0100-5405/1991.

Moreira, S. (1959). Tristeza na laranja Pêra. Boletim de Campo Blemco S.A., 123, 3-4.

Müller, G. W., Baptista-Grassi, C. R., Gazotto, M. C., \& Donadio, L. C. (2002). Old clone of sweet oranges obtained by shoot-tip grafting and preimmunized with a mild CTV strain in the former Seção de Virologia of the Instituto Agronômico, Campinas (IAC). In Proceedings of the 7th International Citrus Seminar (pp. 120). Bebedouro: Estação Experimental de Citricultura.

Müller, G. W., Rodriguez, O., \& Costa, A. S. (1968) A tristeza virus complex severe to sweet orange varieties. In Proceedings of the 4 th International Organization of Citrus Virologists (pp. 64-71). Gainesville: University of Florida Press. Retrieved in 2019, October 30, from https:// escholarship.org/content/qt6xc174wc/qt6xc174wc.pdf

Müller, G. W., Targon, M. L. P. N., \& Machado, M. A. (1999). Trinta anos de uso do clone pré-imunizado Pêra IAC na citricultura paulista. Laranja, 20(2), 399-408.
Navarro, L., \& Juárez, J. (2007). Shoot-tip grafting in vitro. In I. A. Khan (Ed.), Citrus genetics, breeding and biotechnology (pp. 353-364). Wallingford: CABI.

Nonino, E. A. (1995). Variedades de laranjas para fabricação de sucos. Laranja, 16(1), 119-132.

Passos, O. S., Soares Filho, W. S., Barbosa, C. J., \& Ramos, Y. C. (2009) A laranjeira Pêra D-6 CNPMF é portadora de estirpe fraca de VTC e tem sido a base da citricultura do Nordeste e Norte do Brasil (4 p.). Brasília: Embrapa Mandioca e Fruticultura Tropical. Folder. Retrieved in 2019, October 30, from https://www.infoteca.cnptia.embrapa. br/infoteca/bitstream/doc/655322/1/FolderPeraD6.pdf

Pearce, S. C., \& Dobersek-Urbanc, S. (1967). The measurements of irregularity in growth and cropping. Horticultural Science, 42, 295-305. http://dx.doi.org/10 $.1080 / 00221589.1967 .11514216$.

Pio, R. M., Figueiredo, J. O., Stuchi, E. S., \& Cardoso, S. A. B. (2005) Variedades copas. In D. Mattos Junior, J. D. De Negri, R. M. Pio \& J. Pompeu Junior (Eds.), Citros. Campinas: Instituto Agronômico de Campinas/ Fundag, p.37-60.

Ramos, Y.C. (2015). Desempenho horticultural de laranjeiras doces de meia-estação sobre tangerineira 'Sunki' (Tese de doutorado). Escola Superior de Agricultura "Luiz de Queiroz", Piracicaba.

Roistacher, C. N., Blue, R. L., Nauer, E. M., \& Calavan, E. C. (1974). Suppression of tristeza virus symptoms in Mexican lime seedlings grown at warm temperatures. The Plant Disease Reporter, 58, 757-760.

Salibe, A. A., Teófilo Sobrinho, J., \& Müller, G. W. (2002) Sinopse de conhecimentos e pesquisas sobre a laranja Pera. Laranja, 23(1), 221-230. Retrieved in 2019, October 30, from http://s3.amazonaws.com/host-article-assets/citrus rt/59afd21e0e8825e625dde272/fulltext.pdf

Teófilo Sobrinho, J., Pompeu Junior, J., Figueiredo, J. O., \& Tanuri, F. (1990). Seleção de clones de laranjeira Pêra na região de Araraquara. Laranja, 11, 297-308.

Received: Junho 04, 2020

Accepted: December 10, 2020

How to cite: Stuchi, E. S., Girardi, E. A., Silva, S. R., Parolin, L. G., Müller, G. W., \& Donadio, L. C. (2020). Performance of field-selected clones of Pera sweet orange in Northern São Paulo state, Brazil. Citrus Research \& Technology, 41, e1061. https://doi.org/10.4322/crt.21920 